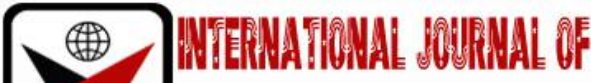

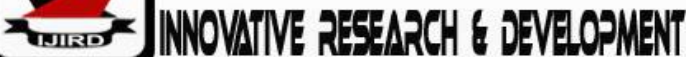

ISSN 2278-0211 (Online)

\section{Farmers' Perceptions towards Climate Change, and Meteorological Data in Kahuzi-Biega National Park Surroundings, Eastern DR. Congo}

Leonard K. Mubalama
Lecturer, Environment and Sustainable Development Department/Centre de Recherche en
Gestion de la Biodiversité et Changement Climatique - CRGBC ISDR Bukavu, Democratic
Republic of Congo
Dieu merci Masumbuko
Assistant Researcher, Environment and Sustainable Development
ISDR Bukavu, Democratic Republic of the Congo
Desire R. Mweze
Antananarivo, Madagascar
Gedeon T. Banswe
Doctoral Student, Department of Economy and Policies of Natural Resources, University of
Remote Sensing and GIS Manager/ Information with Management and Mine Action Program
(IMMAP) Information Management IMMAPICCN/Beni, DR Congo
Pierre Aubin Mirindi
Researcher, DR Congo, University of Kaziba/ South Kivu, Democratic Republic of the Congo

\begin{abstract}
:
Climate change nowadays is recognized as one of the most challenging and complex problem facing the agricultural development globally. However, the vulnerability of climate change on this sector in Africa is more than any other socioeconomic activities. This paper assesses smallholder farmers' perceptions about climate change in the surrounding areas of the Kahuzi-Biega National Park in Eastern DR Congo. We also used thirty nine-year observed climate data (1980-2019) to corroborate farmers' perceptions about climate change. The Mann-Kendall Test and SPSS were used for data analyses, while qualitative data were thematically analyzed. The results showed that from 1980 to 2019 the mean annual rainfall decreased $(R 2=0.11)$ while temperature increased $(R 2=0.43)$.

The major adaptation strategies identified included use of improved varieties and crop rotation (47.78\%), early planting (53.33\%), agroforestry practices (52.23\%), planting early maturing varieties (38.89\%), planting resistant varieties (46.67\%), adoption of irrigation techniques (22.22\%), and Integrated management of soil fertility package (65.55\%). Results of logit regression analysis indicated that the access to extension services, credit, soil fertility, and land tenure are the most important factors that influence farmers' perception and adaptation. The main barriers included lack of information on adaptation strategies, poverty, and lack of information about weather. Even though the communities are highly aware of climate issues, only $44.4 \%$ of farmers have adjusted their farming practices to reduce the impacts of increasing temperature and 40.6\% to decreasing precipitation, giving lack of funds as the main barrier to implementing adaptation measure.
\end{abstract}

Keywords: Climate change, farmers' perceptions, KBNP, rainfall and temperature pattern

\section{Introduction}

Now-a-days, climate change especially, Global climate change is threatening to undo decades of development efforts due to its negative impacts on agriculture, health, environment, roads, and buildings especially in developing countries (Mendelsohn et al. 2006; IPCC, 2007; Stern, 2007). It is a particular threat to the attainment of the Sustainable Development Goals (SDGs) and progress in sustainable development in South Kivu province in Eastern DR Congo. Increasing temperatures and shifting rain patterns across Eastern DR Congo reduce access to food and create effects that impact regions, farming systems, households, and individuals in varying ways. Thus, analyses of the biophysical and socioeconomic factors that determine exposure, adaptation, and the capacity to adapt to climate change are urgently needed so that policymakers can make more informed decisions. There is mounting evidence that smallholder farmers in developing countries are experiencing increased climate variability and climatic change. 
In South Kivu, weather-related events such as prolonged dry seasons, floods, storms, mudslides, extreme rainfall, and delayed/early rains have become more frequent and/or intense. This has left most of the rural poor farmers' food insecure and their livelihoods threatened. It is expected that climate change will include more extreme events and slow onset impacts, such as changes in precipitation and temperature. Climate change is thought likely to have mainly negative impacts upon agricultural production, food security and economic development, especially in developing countries (Hannah et al. 2008). It is now well rehearsed in the literature that the impacts of climate change will be felt most by the poorest who have least resources with which to cope and whose livelihoods are disproportionately reliant on climatesensitive natural resources. Strengthening the adaptive capacity of, and promoting specific agricultural adaptations among, smallholder farmers and organizations will enhance their ability to respond to climate change impacts. New opportunities are arising, including tapping into climate finance mechanisms, which Fairtrade organizations may be able to access to both mitigate and adapt to climate change.

Understanding farmers' perceptions regarding rain-falls had been highlighted in many studies (Simelton et al. 2013). Sub-Sahara Africa (SSA) is among the most vulnerable continents or regions to climate change impacts, because the majority of the SSA population lives in abject poverty, and are heavily dependent on rainfed agriculture for their economic and livelihood sustenance. Climate change nowadays is recognized as one of the most challenging and complex problem facing the agricultural development globally (Tesfahunegn et al. 2016). However, the vulnerability of climate change on this sector in Africa is more than any other socioeconomic activities (Fedoun et al. 2017).

Africa's one of the most important sector is the Agriculture. It holds approximately one-third of the GDP. Almost half workforce of Africa is depending on this field (Ngaira and Musiambo, 2012). Climate change threatens this economy because agriculture in Africa is climate-dependent (Mendelsohn, 2000). The African agricultural sector relies heavily on direct rainfall, and patterns in economic growth closely follow precipitation patterns. Staple crops such as wheat and corn that are associated with subtropical latitudes may suffer a drop in yield as a result of increased temperature. In addition to climate change effects, food production in SSA has not kept pace with the growing population.

Almost half reduction can be noticed by 2020. It can drastically goes up to $90 \%$ at the end of 2100 . The most affected farmers will be small scale farmers. As per a report of UNDP (2006) Report on Human Development, 36\% of malnourished people are from sub-Saharan Africa. This contributes 17\% of the world's malnourished population. People depending heavily on the agriculture, hampered by the climate change and land degradation, fluctuating rainfall etc. (Ngaira and Musiambo, 2012).

The 4th Assessment Report of the (IPCC) Intergovernmental panel on climate change 2007 confirmed that 'Africa is one of the most vulnerable continents to climate variability and change because of multiple stresses and low adaptive capability. Climate change is the gravest and most complex problem impacting the planet and its people in the twenty-first century. Africa is particularly vulnerable to climate change. Climate change is in fact one of the most serious environmental, social and economic threats the world has ever faced affecting different sectors of life. It particularly has the potential to deepen poverty, food insecurity, poor livelihoods and unsustainable development especially in developing countries (FAO 2005; IPCC 2007). So, anticipating or adapting to climate change impacts become a necessity in order to minimize their consequences on human well-being and on the environment (Locatelli et al. 2008; Sonwa et al. 2012).

As per Thompson and Scoones (2009); Adger (2006); Below et al. (2015), in agricultural domain, climate change is contributing the most. In SSA, extreme levels of drought are hampering the food security (Kebede et al. 2011; Songok et al. 2011). According to Porter et al. (2014), African food production is getting mostly affected by the climate change. Food access and food utilization contributes significantly in the food security literature (Misselhorn 2005). Earnings, physical condition and assets are also affecting the resident's well-being (Bashir and Schilizzi 2013) as well as the climate change impacts. A growing number of studies have been published regarding farmers' self-assessment of risk associated with climate change hazards as a key in improving climate change adaptation (IPCC, 2014; Niang et al. 2014). Perceiving climate variability is the first step in the two-step process of adaptation (Deressa et al. 2009). Exploring farmers' perception of climate variability and barriers to adaptation is, therefore, essential for adaptation research. For majority of the farmer, rainfall and temperatures affect the production of food mostly. For the farmers, droughts perceived as bad years(Ahmed et al. 2011, Rowhani et al. 2011, Sovacool et al. 2017). The literature shows, change in perception on climate change at the local and global levels (Paavola, 2008; Kilembe et al. 2012; Below et al. 2015, Sieber et al. 2015) and point out that farmers' perception are very important.

This study examined farmers' perceptions of long-term climate change, adaptation measures undertaken, and the determinants of adaptation (Table 5) decisions based on household surveys conducted in surrounding areas of the KahuziBiega National Park (KBNP). This analysis aimed to strengthen understanding about farmers' decision-making process to enable policymakers and other stakeholders to support adaptation to climate change at the farm-level. While agricultural adaptation to climate change involves more than farm-level changes in farming practices, farm-level adaptations are an essential component of adaptation of agricultural systems. To address issues and concerns, there is a need for a comprehensive assessment of farmers' perceptions and adaptations to climate change in KBNP surrounding areas.

This paper aims to better understand the extent to which the perceptions of smallholder farmers about climate change hazards can be reliable in the KBNP highland sector surrounding areas.This article seeks to: (i) identify KBNP surrounding areas farmers' perceptions of climate and climate variations, and changes; (ii) examine the nature of meteorological evidence for the perceived climate variability and change; (iii) document farmers' responses to perceived climate variability and change; (iv) discuss why discrepancies may occur between farmers' perceptions and meteorological observations of rainfall, and ( $\mathrm{v}$ ) recommend plausible policy interventions that match farmers, perceptions, experiences, adaptation strategies and coping mechanisms in the study area. 


\section{Material and Methods}

\subsection{Biophysical Description of the Study Area}

Straddling the Albertine Rift and the Congo Basin, KBNP is an exceptional habitat for the protection of the rainforest and the eastern lowland gorilla, Gorilla berengeigraueri. Extending over 600,000 ha, are dense lowland rainforests as well as Afro-montane forests, with bamboo forests and some small areas of sub-alpine prairies and heather on Mounts Kahuzi (3,308 m) and Biega $(2,790 \mathrm{~m})$. The Park contains a flora and fauna of exceptional diversity, making it one of the most important sites in the Rift Albertine Valley, it is also one of the ecologically richest regions of Africa and worldwide. In particular, the most important world population of eastern lowland gorillas (or Grauergorlla), sub-species endemic to the Democratic Republic of the Congo (DRC) and listed under the endangered category on the IUCN Red Data Book, uses the mosaic of habitats found in the property. The park is a UNESCO World Heritage Site, inscribed in 1980 for its unique biodiversity of rainforest habitat and its eastern lowland gorillas' population.

A corridor of $7.4 \mathrm{~km}$ (4.6 mi) width joins the mountainous and lowland terrain. The eastern part of the park is the smaller mountainous region measuring $600 \mathrm{~km}^{2}$ (230 sq mi); the larger part measures $5,400 \mathrm{~km}^{2}(2,100 \mathrm{sq} \mathrm{mi})$ and consists mainly of lowland drained by the Luka and Lugulu rivers which flow into the Lualaba River. Two dormant volcanoes are set within the park's limits and lend their names to it: Kahuzi $(3,308 \mathrm{~m}(10,853 \mathrm{ft}))$ and Biega $(2,790 \mathrm{~m}$ $(9,150 \mathrm{ft})$. The park receives an average annual precipitation of $1,800 \mathrm{~mm}$ (71 in). The maximum temperature recorded in the area is $18^{\circ} \mathrm{C}\left(64^{\circ} \mathrm{F}\right)$ while the minimum is $10.4^{\circ} \mathrm{C}\left(50.7^{\circ} \mathrm{F}\right)$.

The KBNP harbors three main vegetation types according to the altitude, including lowland forests (stretching from $700 \mathrm{~m}$ to $1250 \mathrm{~m}$ a.s.l), sub montane forests (from $1250 \mathrm{~m}$ to $1800 \mathrm{~m}$ ) and highland forests from $1800 \mathrm{~m}$ to $3315 \mathrm{~m}$ a.s.l (Fischer, 1996; Mangambu, 2013). This study covers only the highland forests (Figure. 1). The orographic effects of the Jos-Plateau and the Kagoro Hills have positive influence on the climate of the study area influencing rainfall, temperature and relative humidity.

The KBNP is established in two main climatic zones. The lowland areas undergo an equatorial climate where it rains almost throughout the year. Precipitations are high and can reach more than $2600 \mathrm{~mm}$; temperature varies between 15 and $25^{\circ} \mathrm{C}$. In the highland areas and sub montane forests, the climate is characterized by 3 to 4 months of dry season and lower rainfall (mean: $1900 \mathrm{~mm}$; Fischer, 1996).The highlands are dominated by hills and marshes. They are located in the Albertine rift, a biodiversity hotspot (Plumptre et al. 2008). In terms of phytogeography, the highlands are part of the afromontane center of endemism but the lowlands belong to the guineo-congolese center of endemism (White, 1986).

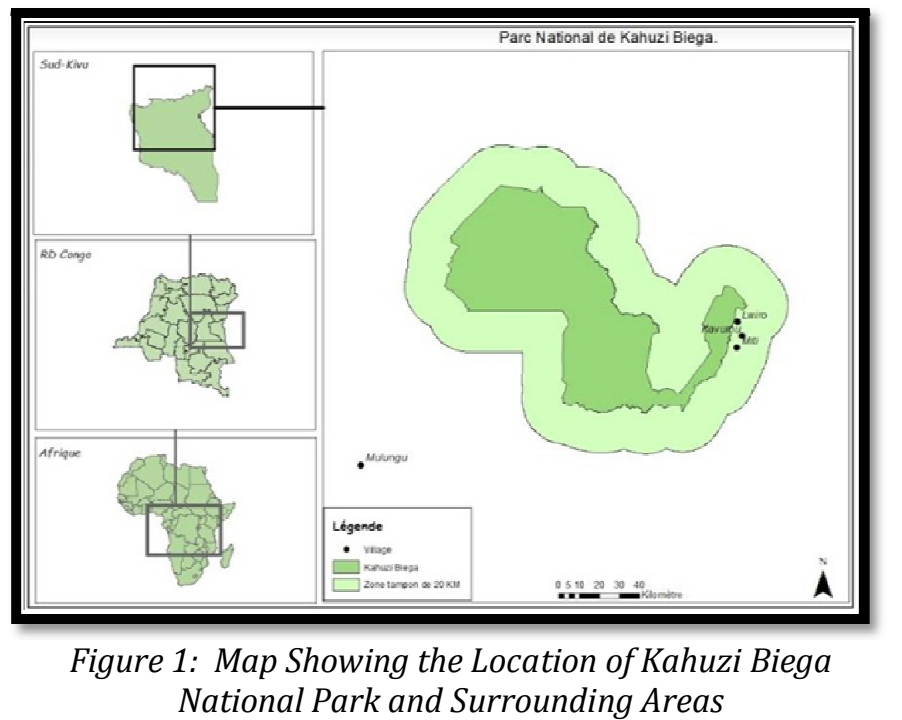

\subsection{Data Collection and Processing}

Primary data were collected from September 2017 to March 2019 from the area highlighted in Figure 1. Both quantitative and qualitative data have been collected from the primary and secondary sources. Purposive sampling has been employed to collect the data. The description of the sample has been shown in the Table 1.Similar methodology has been adopted by Simelton et al. (2013) and Gebreeyesus et al. (2017). After selecting the study area through purposive sampling, simple random sampling was used to select the villages. Sample size of farmers is 180 . Three communities were selected based on their agricultural production and proximity with the KBNP (NtahombaganaMitima, 2019; Nyamunyere Malira, 2019).Focus has been placed in research questions on religion, ethnicity, health statuses etc.

For doing qualitative research, six focus groups were conducted. Each focus group consists of 8 to 18 farmers. A total of five themes have been focused for this study; namely: socio-economic, climate change information, perception, perception towards rain fall patterns etc.

At the initial stage, general understanding toward climate change and the level of confidence of farmers have been studied. They also requested to provide details of their strategies. Second, we asked questions on whether the governing policy gave any guidelines they are following or not. Third, through open-ended and non-prescriptive questions, benefits, 
risks and barriers of integrating adaptation and mitigation strategies have been studied. The rainfall and temperature data from 1980 to 2018 were collected from AgMERRE Meteorological dataset (2019).

\begin{tabular}{|c|c|c|c|}
\hline Variable & Frequency & Percentage & Mean \\
\hline Age Below 21 & 6.0 & 3.33 & \\
\hline $21-30$ & 10 & 5.58 & \\
\hline $31-40$ & 48 & 26.67 & 47.5 years \\
\hline $41-50$ & 60 & 33.33 & \\
\hline $51-60$ & 28 & 25.56 & \\
\hline Above 60 & 28 & 25.56 & \\
\hline \multicolumn{4}{|l|}{ Gender } \\
\hline Male & 153 & 85 & \\
\hline Female & 27 & 15 & \\
\hline \multicolumn{4}{|l|}{ Level of education } \\
\hline None & 64.5 & 35.83 & \\
\hline Primary & 62.5 & 34.72 & \\
\hline Secondary & 31.5 & 17.51 & \\
\hline Tertiary & 23.5 & 11.94 & \\
\hline \multicolumn{4}{|l|}{ Years of farming experience } \\
\hline $1-10$ years & 18 & 10.00 & \\
\hline $11-20$ years & 48 & 26.67 & \\
\hline $21-30$ years & 37 & 20.55 & 37 years \\
\hline $31-40$ years & 57 & 31.67 & \\
\hline Above 40 years & 20 & 11.11 & \\
\hline \multicolumn{4}{|l|}{ Farm size (ha) } \\
\hline $0.1-0.5$ ha & 126 & 70.0 & \\
\hline $0.6-0.10 \mathrm{ha}$ & 28 & 15.5 & $0.3 \mathrm{ha}$ \\
\hline Above $0.10 \mathrm{ha}$ & 26 & 14.5 & \\
\hline \multicolumn{4}{|l|}{ Household size } \\
\hline $1-10$ & 89 & 49.45 & 6.2 \\
\hline $11-20$ & 53 & 29.44 & \\
\hline $21-30$ & 26 & 14.44 & \\
\hline $31-40$ & 12 & 6.67 & \\
\hline \multicolumn{4}{|l|}{$\begin{array}{l}\text { No of social organizations } \\
\text { belonged }\end{array}$} \\
\hline None & 60 & 33.33 & \\
\hline $1-2$ & 83 & 46.11 & 1 social org. \\
\hline $3-4$ & 29 & 16.11 & \\
\hline Above 4 & 8 & 4.45 & \\
\hline \multicolumn{4}{|l|}{ Annual income level (CDF) } \\
\hline Below CDF $500,000.00$ & 113 & 62.78 & \\
\hline $500,000-$ CDF $1000,000.00$ & 55 & 30.55 & CDF $391,753.20$ \\
\hline Above CDF $1000,000.00$ & 12 & 6.67 & \\
\hline \multicolumn{4}{|l|}{ Past 5 years (CDF) } \\
\hline None & 118 & 65.28 & \\
\hline $1,000-500,000$ & 36 & 19.72 & \\
\hline $501,000-1,000,000$ & 18 & 10.28 & CDF52167.6 \\
\hline Above $1,000,000$ & 8 & 4.72 & \\
\hline \multicolumn{4}{|l|}{ Land tenure system } \\
\hline Inherited & 121 & 67.22 & \\
\hline Purchased & 12 & 6.67 & \\
\hline Leased & 8 & 4.44 & \\
\hline Hired & 16 & 8.89 & \\
\hline Family/community & 23 & 12.78 & \\
\hline
\end{tabular}

Table 1: Distribution of Respondents According to Their Socioeconomic Characteristics ( $=180)$ CDF: Congo Democratic Currency

Source: Field Survey Data, 2017-2019

\subsection{Data Analyses}

A closed ended questionnaire has been used as a data collection instrument. Statistical Package for Social Science (SPSS 25) has been used for running quantitative tests. Variability of temperature and rainfall on yearly and monthly levels has been captured from 2010 to 2019. The analysis has been done using the Mann-Kendall Test and Microsoft excel (window 19). The descriptive study has been done using descriptive statistics. A binary logit model can be use to study this type of scenario (Fosu-Mensah, 2010; Mustapha et al. 2012; Muzamhindo et al., 2015):

$Y=f(X 1, X 2, \ldots, X 6)(1)$ 
where $\mathrm{Y}$ is the adaptation status $(1=$ farmers who adapted, $0=$ farmers who did not adapt $)$. The multinomial logit model was used to determine the factors influencing the choice of farmers to use a particular method of adaptation to climate change (Sani. 2014, Tazeze et al. 2014).

The reduced form of the model is as follows (Loko et al. 2012):

$\mathrm{Yi}=\mathrm{f}(\mathrm{X} 1, \mathrm{X} 2, \ldots, \mathrm{X} 6)(2)$

where $\mathrm{Yi}$, the polychotomic dependent variable, is the adaptation method chosen by the producer and X1 to X6 are the explanatory variables. Based on the data collected on the adaptation strategies developed by farmers in the study area, the dependent variable (Yi) is coded 1 for 'no adaptation,' 2 for 'Crop-livestock diversification,' 3 for 'Use of improved varieties, chemical fertilizers and pesticides,' 4 for 'Agroforestry and perennial plantation (thee, tree species),' 5 for 'Diversification of income-generating activities' and 6 for 'Multiple coping strategies.' The explanatory variables include:

$\mathrm{X} 1$ = Farming experience, $\mathrm{X} 2$ = Farm size, $\mathrm{X} 3$ = education level, $\mathrm{X} 4=$ Gender, $\mathrm{X} 5$ = Percentage of farm income and X6 = Belonging to a farmers' organization. Tazeze et al. (2012) gave more details on the hypothetical relationships between these variables and adaptation to climate change. The standardization of a category, defined as 'base category' or 'reference state,' was used to estimate the model of multinomial logical regression (Loko et al. 2012, Tazeze et al. (2012). In this study, the category 'no adaptation' was used as the base category.

The 1980-2019 meteorological data is normally taken for baseline (AgMERRE, 2019), because this is the period when climate change effects manifested on a small-scale, if at all. This timescale was selected, on the one hand, to correlate with the long-term strategic planning period, and on the other, to avoid the ambiguity of various climate scenarios. Data were verified through a re-analysis, i.e. a test of how well the model correlates with observations after 2019. In reality, it is only possible to forecast an average annual and average seasonal temperature change, as well as changes in the minimum and maximum temperature, with a confidence interval. It is also possible to identify precipitation trends (average), mean and maximum potential wind speed. It seems like it is not too much. However, projections of any other parameters would not be reliable.

\section{Results}

\subsection{Socioeconomic Characteristics of Sampled Households}

Table1 depicts the socioeconomic characteristics of the respondents as follows: The total sampled households were 180, of which, the majority (85\%) of the respondents were males with only $15 \%$ as females. The average household size for the sampled households was 6.2. Most (36.7\%) of the respondents were aged between 40 - 55 years with a mean age of 47.5 years. This shows that smallholder farmers in the study area were mostly middle-aged people who were still strong and energetic and were most likely to adopt more techniques to cope with climate change events. The farm size varied from 0.1 to 0.5 ha ( 0.3 ha on average) for $70.6 \%$ and 0.6 to 0.9 ha ( 0.75 on average) for $10.6 \%$ of rural population (Cirimwami et al. 2020. The education distribution of farmers show that were mostly illiterates. This low level of education is capable of limiting their access to accurate information on climate change and hence their adaptive capacity might be very low. The mean farm size of the food processor respondents was 1.2 ha (Cirimwami et al. 2020). Majority (50.5\%) of the respondents belonged to one or two social organizations, $34.65 \%$ did not belong to any social organization while $14.85 \%$ had between 3-4 organizations. This implies that most of the farmers participated in social organizations. This will provide avenue for information sharing thereby enhancing adoption capacity. The mean annual income was CDF326, 461.00. This implies that farmers in the study area were mainly low-income earners. Majority (83.5\%) of the respondents did not use any credit facility during the past five years. Only 8.7\% received between CDF100,000 - CDF500, 000 as credit. Majority (56.8\%) of the respondents inherited their farm lands while $43.2 \%$ used private borrowed land.

\subsection{Smallholder Farmers' Perception on Temperature and Rainfall}

\subsubsection{Overall Perception}

The farmers' attitude towards temperature and rainfall are changing in many ways. Figure 1 represents the main causes as per the perception of the farmers. Majority indicated rainfall and temperature as the main influencing factor. Regarding answering the question that what these changes consist of, rainfall disturbances, shortening of the small dry season, increasing of temperature have been answered by most of the farmers (see Figure 2). To answer the question that how the rainfall patterns had changed, all the respondents had observed changes in the overall climate pattern (Figure 3).

\section{Results and Discussion}

\subsection{Results from Meteorological Data Analyses}

\subsubsection{Rainfall}

As per Challinor et al (2007), the yearly rainfall and situation of pond are highly correlated. To ascertain actual farmers' perceptions on climate at a farm level, we further analyzed the wet spells. These are the number of days that received rainfall in a particular month. For the past 39 years the number of wet spells has significantly fluctuated at the decreasing trend. In general, it was noted that the rains of season A, which in time, began on September 15 and those of the season B (February-May) which started on February 15 have been postponed by 2 weeks to 1 month (specific case of lowland area). The consequences are that: corn (Zea mays L.) in season B is attacked by caterpillars because of the early dry season; there is resurgence of locusts against cassava; cassava pill scale. There is also an early shutdown of the rains by 
campaign on the two growing seasons. The rains in May stop suddenly and go until June which is become rainy. This has led smallholder farmers to adopt a new agricultural calendar (Byenda et al. 2019). The strategy most practiced at lowland area is the adoption of plants tolerant and precocious plants while at high and medium altitudes more than $70.4 \%$ of peasants adopt no strategy. Less than $27.5 \%$ of the population use improved and early varieties and irrigation. The majority of food crops grown suffer from biotic stresses due to climatic disturbances, all the more so since more than half of those surveyed confirm that there is proliferation and appearance of new diseases and pests. These are, for example, the brown streak on cassava (Manihot esculenta Crantz) in lowland areas and the bacterial wilt on banana (Musa, sp.) in highland and medium altitudes, Crops such as rice (Oryza sativa), beans (Phaseolus vulgaris), corn (Zea mays, L), cassava (Manihot esculenta) and banana (Musa, sp) are also prone to diseases and pests. Sweet potatoes (Ipomoea batatas), on the other hand, are least attacked crop, probably because of their tolerance and elasticity. Food crops grown suffer from water deficiency, as the majority of those surveyed claim. Crops such as beans (Phaseolus vulgaris), rice (Oryza sativa) and corn (Zea mays, L) are the ones most affected by the lack of rains in lowland and highland areas, only the beans suffer from excess rains in medium altitudes because they only need it during the first days before flowering. Other crops such as cassava and sweet potatoes are moderately water deficient because the latter are more or less flexible, this property makes them easy to adapt to difficult conditions to survive.

Cassava (Manihot esculenta) is more attacked at high altitudes where many diseases are noted today; on the other hand, in medium and low altitude this speculation behaves and produces well. Most food crops grown in South Kivu suffer from water deficiency. Crops such as cassava (Manihot esculenta) and sweet potatoes (Ipomoea batatas) are moderately water deficient because the latter are more or less plastic, this property makes.Them easy to adapt to difficult conditions.

Some rainfall also initiated from airstreams of Atlantic origin (Latif et al. 1999; Tierney et al. 2011). Precipitation trends of the Great Lakes Region, also affected overall assessment (e.g. Stampone et al. 2011). Herrmann and Mohr (2011) identified variability in precipitation seasonality. Lyon and DeWitt (2012) had identified oceanic forcing as a dominant causative factor. The trend for decreasing rainfall during the long rains season over the past decade across East Africa identified by Lyon and DeWitt (2012). As indicated in Shongwe et al. 2011, there is a strong model consensus that precipitation will increase significant over the course of the 21st century in direct response to anthropogenic warming of the global atmosphere in the GLR. Taken collectively, the models indicate more intense wet seasons, increased intensity of high rainfall events and for less severe droughts (Shongwe et al. 2011), but significant increases are not projected to begin for several decades. Key as pects related to atmosphere's water vapor, temperature etc. of the consensus scenario developed from multiple model simulations of evolving future climatic states across the GLR, including KBNP surrounding areas.

Land use/land cover changes remain significant drivers of climatic change at local scales, but also in aggregate for the whole region. Changes in land surface type drive important changes in radiative transfers, evapotranspiration and runoff. Conversion of forests to croplands in particular causes marked changes in climatological characteristics across the deforested areas.

\subsubsection{Temperature}

The mean annual temperature patterns increased increasingly at a rate of R2 $=0.43$ while those of January, February, and March increased significantly at $\mathrm{R} 2=0.03,0.07$, and 0.22 respectively. This particular trend reflects what happens in global temperature scenarios, as presented in various climate models (IPCC, 2012, IPCC, 2014). No trend in diurnal maxima has been observed in western Kenya demonstrate (Christy et al. 2009); these patterns therefore match signals from many other terrestrial environments (IPCC, 2007).

Figure 1 shows that $84 \%$ of farmers interviewed perceived a long-term change in temperature through increasing temperature. This means that farmers are well aware of climate change, as more than $80 \%$ of farmers interviewed perceived an increasing temperature and a decreasing precipitation trend. This is in line with the finding of Gbetibouo (2009), who reported that majority of the respondents in three regions of Limpopo River Basin of South Africa, respectively, were well aware of changes in long-term climate patterns particularly increased variability in precipitation. The perceived rise in temperatures were attributed to the depletion of the forest resources, increased population, and to other factors. A limited number of the respondents could not give any reason for the cause of the perceived change in temperatures. To verify farmers perceived long-term change in temperatures, the historical annual mean temperature data for the study area from 1980 to 2019 (39 years) were analyzed. This confirmed a slightly increasing trend in temperature particularly in 2016; 2017 and 2019 (Figure 4)

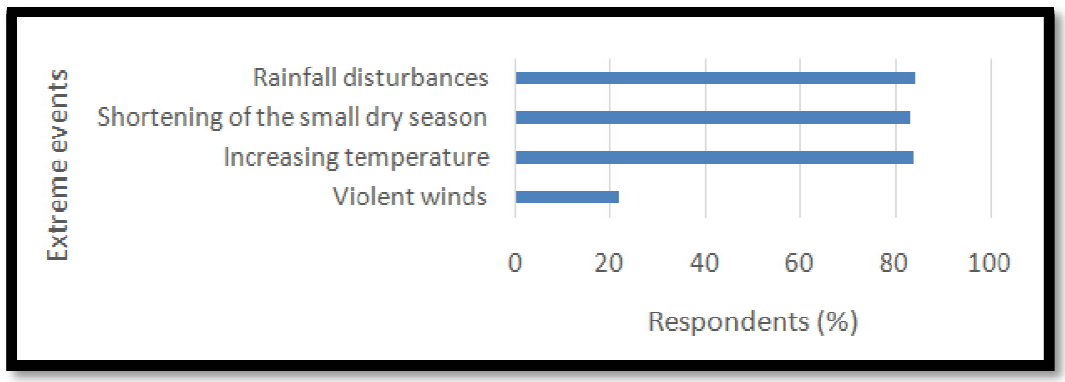

Figure 2: Farmers Perception of Change in Temperature (\%) during the Past 20 Years in KBNP Surrounding Areas 


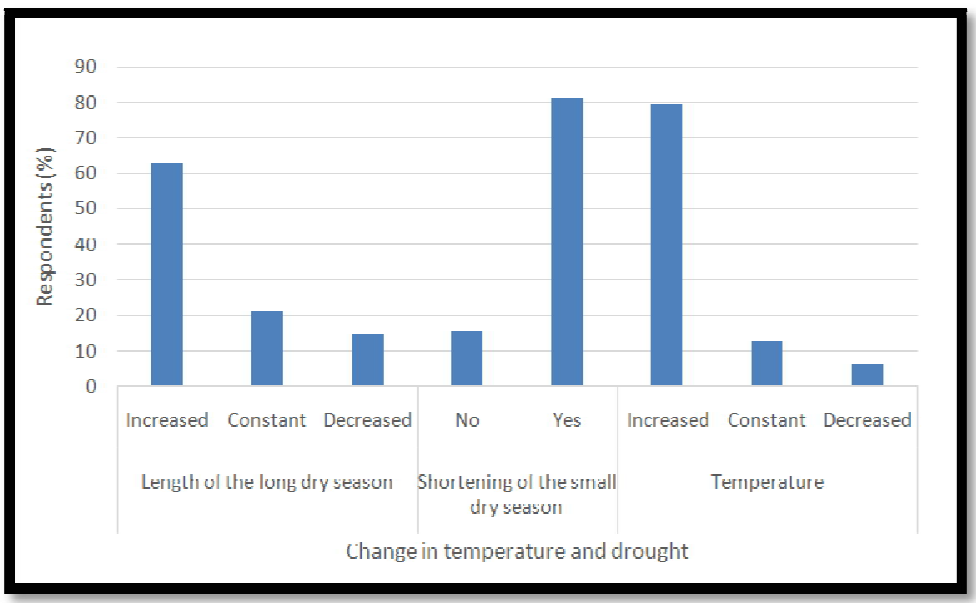

Figure 3: Farmers Perception of Change in Temperature and Drought (\%) during the Past 20 Years in KBNP Surrounding Areas

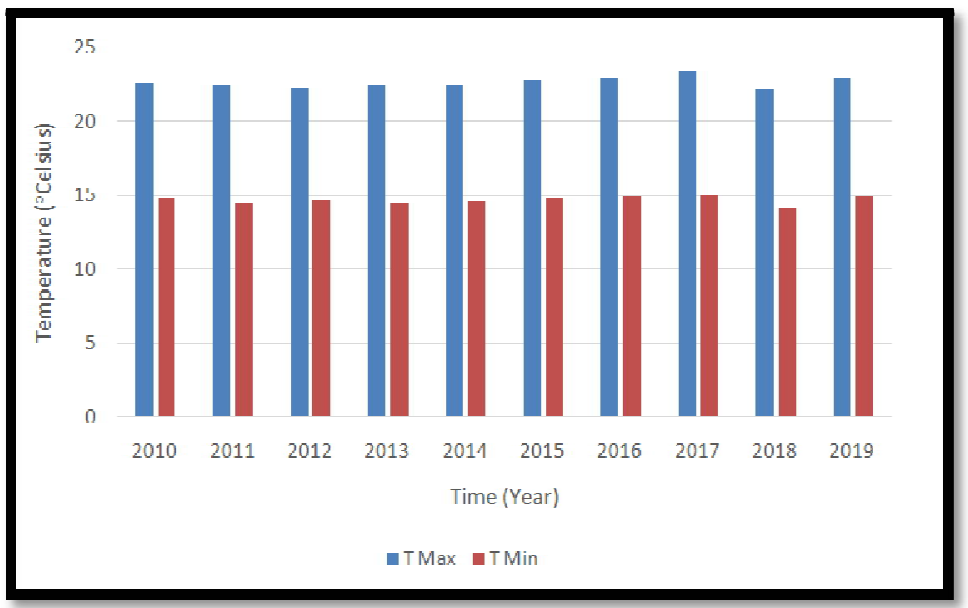

Figure 4: Historical Mean Annual Temperature (C) in the KBNP Surrounding Areas (2010-2019)

Farmers' perceived change in precipitation was mainly in terms of its distribution within the growing season. Sixty seven percent of the respondents perceived late rainfall pattern. A verification of farmers' perception on precipitation using historical annual rainfall data showed a decreasing trend (Figure. 6) with high rainfall value in 2011 (2024.95 $\mathrm{mm})$ and in 2018 (1940.17 mm). Thus, the distribution of rainfall within the season is more important than annual value. Eighty one percent of respondents perceived a shortening of the small dry season while $61.4 \%$ perceived the rainy season length decreasing (Figure 5) and the total of $62.7 \%$ perceived the length of the long dry season increasing (Figure 3).

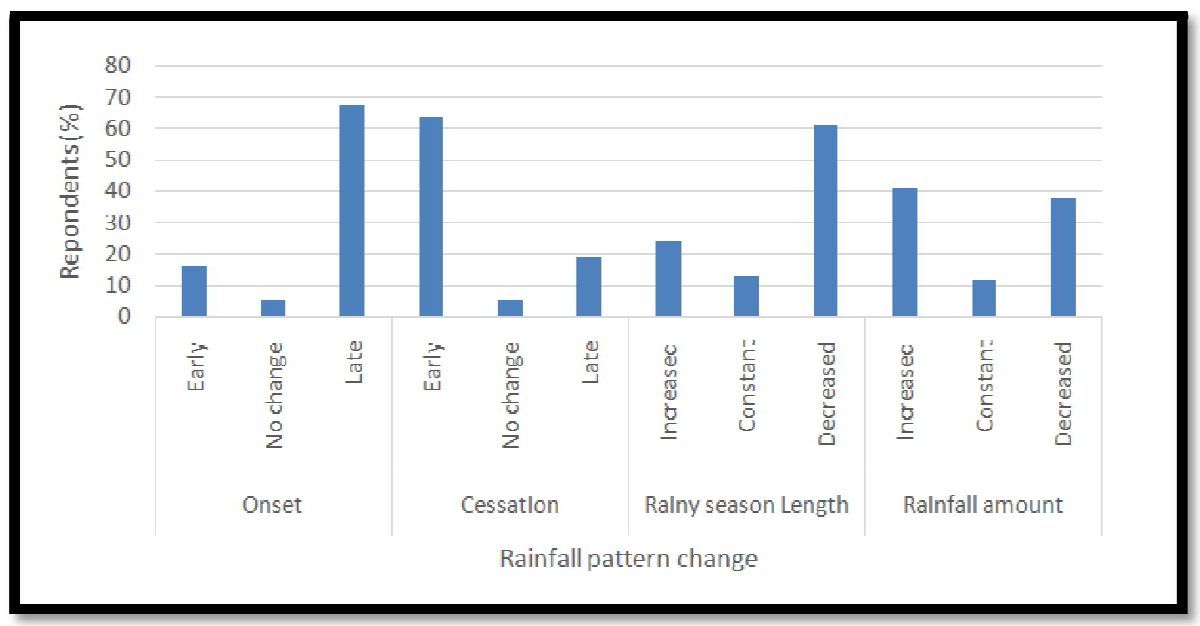

Figure 5: Farmers Perception of Changes in Precipitation (\%) during the Past 20 Years in KBNP Surrounding Areas 


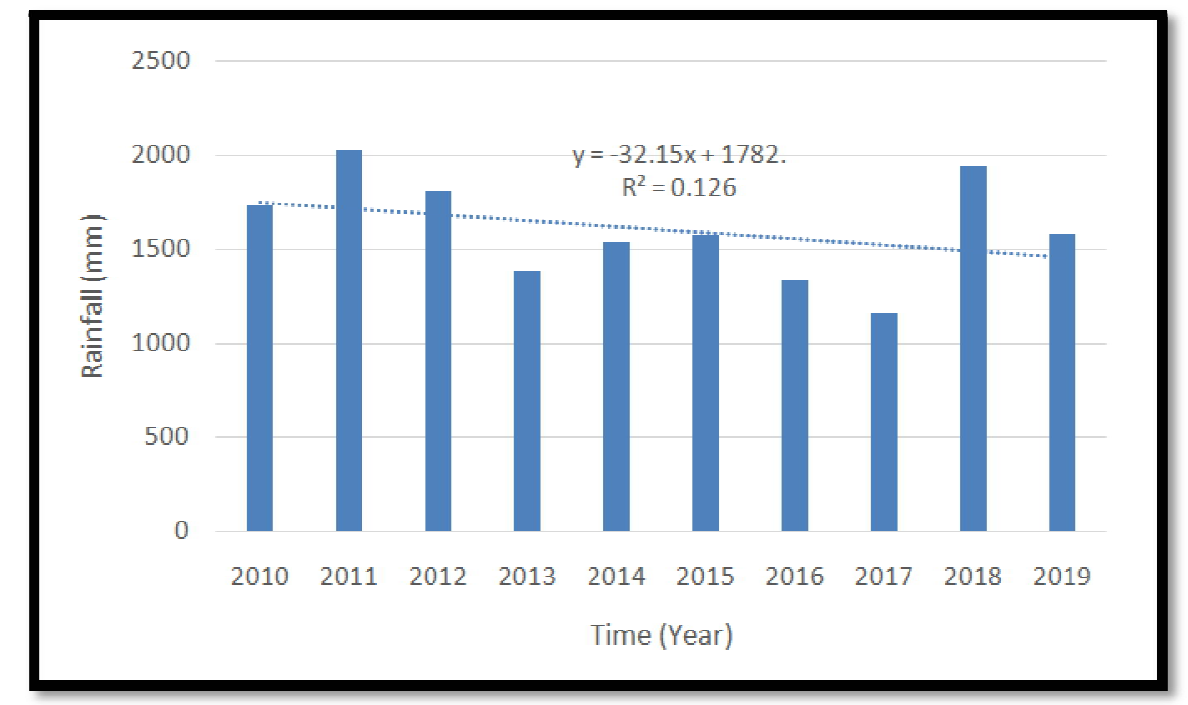

Figure 6: Historical Mean Annual Rainfall (Mm) in the KBNP Surrounding Areas (2010-2019)

\subsubsection{Determinants of Farmers' Choice of Adaptation Strategies}

The analysis of multinomial logical regression to determine the factors influencing the choice of farmers to use a particular method of adaptation to climate change revealed that farming experience and educational level significantly affected the use of different methods of adaptation (Table 3 and Table 5).

- Farming experience: outcome indicated that farming experience is significantly affected with the all strategies.

- Educational level: this has positive and strong effect on the dependent variable. All adaptation strategies are influenced by this factor.

- Farm size: Farm size had a positive and significant impact on multiple coping strategies. The larger the farm, the more farmers opted for the combination of several coping strategies.

- Gender of household head: The results indicate that being female, as a household head, increases the chance to choose diversification of income-generating activities as adaptation to climate change.

\subsubsection{Spatial Clustering of Climate Change Perceptions}

As shown in the above section, a large number of farmers believe the climate has become hotter and drier. As suggested by Maddison (2007), this perception might be a case of prominence bias in questionnaires dealing with climate change. It's likely that some respondents provided answers during the interview that the enumerators were more interested in hearing. Thus, validation of the respondent's assessment of climate change with his/her neighbors' responses would provide more confidence that the responses were objective and not subjective. We employed Moran's I test for spatial autocorrelation with an inverse distance weights matrix on the portion of farmers who perceive particular types of climate change within a given area. The results (Table 2) suggested that neighboring farmers agree that temperature is increasing and rainfall is decreasing with a change in the timing. These results are evidence that farmers are capable of perceiving changes in climate.

\begin{tabular}{|llll|}
\hline $\begin{array}{l}\text { Perception } \\
\text { of temperature }\end{array}$ & Moran I statistics & Perception of rainfall & Moran I statistics \\
\hline Increased temperature & $0.044^{* *}$ & Increased rainfall & -0.013 \\
Decreased temperature & 0.002 & $\begin{array}{l}\text { Decreased rainfall } \\
\text { Change in the timing }\end{array}$ & $0.125^{* *}$ \\
More or less extreme & 0.001 & $\begin{array}{l}\text { Change in frequency of } \\
\text { droughts/floods }\end{array}$ & -0.007 \\
No change & -0.003 & No change & 0.003 \\
& & & \\
\hline
\end{tabular}

Table 2: Moran's, I Test Spatial Correlation of Climate Perception Note: ** Significant at 1\% Level * Significant at 5\% Level

Types of adaptation measures used by the respondents Table 3 shows the various adaptation measures practiced by the respondents. These include the practice of organic farming (65.33\%), use of resistant varieties (53.33\%), agroforestry practice $(52.67 \%)$, crop diversification (48\%) and early planting of crops (46.67\%), among others. These measures are aimed at maximizing yields and ensure food security. Crop diversification which implies growing a number of different crops in the same plot or in different plots reduces the risk of complete crop failure as different crops are affected differently by climate events. Nhemachena and Hassan (2007) reported that farmers are using crop management 
practices that include use of irrigation, water and soil conservation techniques and varying planting and harvesting dates to ensure that critical, sensitive growth stages that do not coincide with very harsh climatic conditions in the season.

\begin{tabular}{|lll|}
\hline \multicolumn{1}{|c}{} & & \\
\hline Uypes of adaptation measure & Frequency & Percentage \\
crop rotation & 86 & \\
Early planting of crops & 96 & 47.78 \\
Agroforestry practices & 94 & 53.33 \\
Planting early maturing varieties & 70 & 52.23 \\
Planting of resistant varieties & 84 & 38.89 \\
Adoption of irrigation techniques & 40 & 46.67 \\
Integrated management of soil fertility package & 118 & 22.22 \\
& & \\
\hline
\end{tabular}

Table 3: Distribution of Respondents According to Types of Adaptation Measures Used (N=180) Multiple Responses Source: Field Survey Data (2017-2019)

Basically, the resilience strategies developed by households are the adoption of the Integrated Management of Soil Fertility package, agroforestry practices, early planting of crops, use of improved varieties and crop rotation combined with the reorganization of the agricultural calendar (Byenda et al. 2019; Cirimwami et al. 2019).

\subsubsection{Determinants of Adaptation Measures to Climate Change}

Regression analysis (in table 6) shows that farming experiences, number of extension contacts per year, income level and type of land tenure system are significant factors at $10 \%$ confidence interval. Age, educational level, and farm credit amount are also significant at this confidence interval. The more the farming experience the more adaptation strategies can be taken by the farmers. The R square value of 0.653 (Table 4) implies that about $65 \%$ of the adaptive capacity of the respondents was determined by their socio-economic characteristics.

\begin{tabular}{|c|c|c|c|c|c|}
\hline \multirow[t]{2}{*}{ Model } & \multicolumn{5}{|c|}{ Unstandardized Coefficients Standardized Coefficients T Sig. } \\
\hline & B Std. & Error & Beta & & \\
\hline Factor & 50.598 & 13.034 & - & 4.658 & .000 \\
\hline Age in years & -.603 & .271 & -.287 & $-\overline{2.672}$ & $.034^{*}$ \\
\hline Sex of resp. & 6.854 & 6.028 & .084 & 1.364 & .308 \\
\hline Farm exp in years. & 1086 & .313 & .479 & 4.158 & $.001 * * *$ \\
\hline Years of schooling & -.696 & .388 & -.148 & $\overline{1.797}$ & $.089^{*}$ \\
\hline $\begin{array}{l}\text { Farm size in hectares } \\
\text { No. of persons in }\end{array}$ & -.032 & .328 & -.007 & -.099 & .921 \\
\hline household & -.51 .5 & .111 & -.036 & -.232 & .322 \\
\hline No. of extension & -.145 & .028 & -.326 & -5.142 & $.000 * * *$ \\
\hline $\begin{array}{l}\text { No. of social } \\
\text { organizations }\end{array}$ & 1.333 & 1.489 & 060 & 895 & 372 \\
\hline $\begin{array}{l}\text { Annual income } \\
\text { in CDF }\end{array}$ & $\begin{array}{l}2.99 \mathrm{E} \\
005\end{array}$ & .000 & .354 & 5.184 & $.000 * * *$ \\
\hline $\begin{array}{l}\text { Amount of credit } \\
\text { received in CDF }\end{array}$ & $\begin{array}{l}-2.66 \mathrm{E} \\
005\end{array}$ & .000 & -.145 & - 2.297 & $.023^{*}$ \\
\hline $\begin{array}{l}\text { Type of tenure } \\
\text { System }\end{array}$ & -4.009 & 1.112 & -.228 & $\overline{3.605}$ & $.000 * * *$ \\
\hline
\end{tabular}

Table 4: Results of Regression Analysis on the Effects of Selected Socioeconomic Characteristics of the Respondents on Their Adaptive Capacity $R 2=0.653, *=$ Significant at $10 \%, * * *=$ Significant at $1 \%$

4.1.6. What Will Be the Major Ways in Which Rural People Adapt to Climate Change?

Rural people, in accordance to their knowledge, resources, and networks, adapt to climate change. But governments and other outside have to assist them.

\subsubsection{Limits and Constraints to Rural Adaptation}

As per the study, high yield maize in Zambia, production and price risks can create problem and can prevent rural households from getting benefitted from technological change (Langyintuo and Mungoma, 2008). A household with better market access generally has higher income (Cunguara and Darnhofer, 2011). Learning, marketplace, credit, and information about adaptation are essential to study (Hassan and Nhemachena, 2008).

Bryan et al. (2009); Deressa et al. (2009); Ringer (2010), studied the perception and uncertainty levels regarding accessing to information. Moumouni and Idrissou (2013) did studies on the agricultural technologies. 


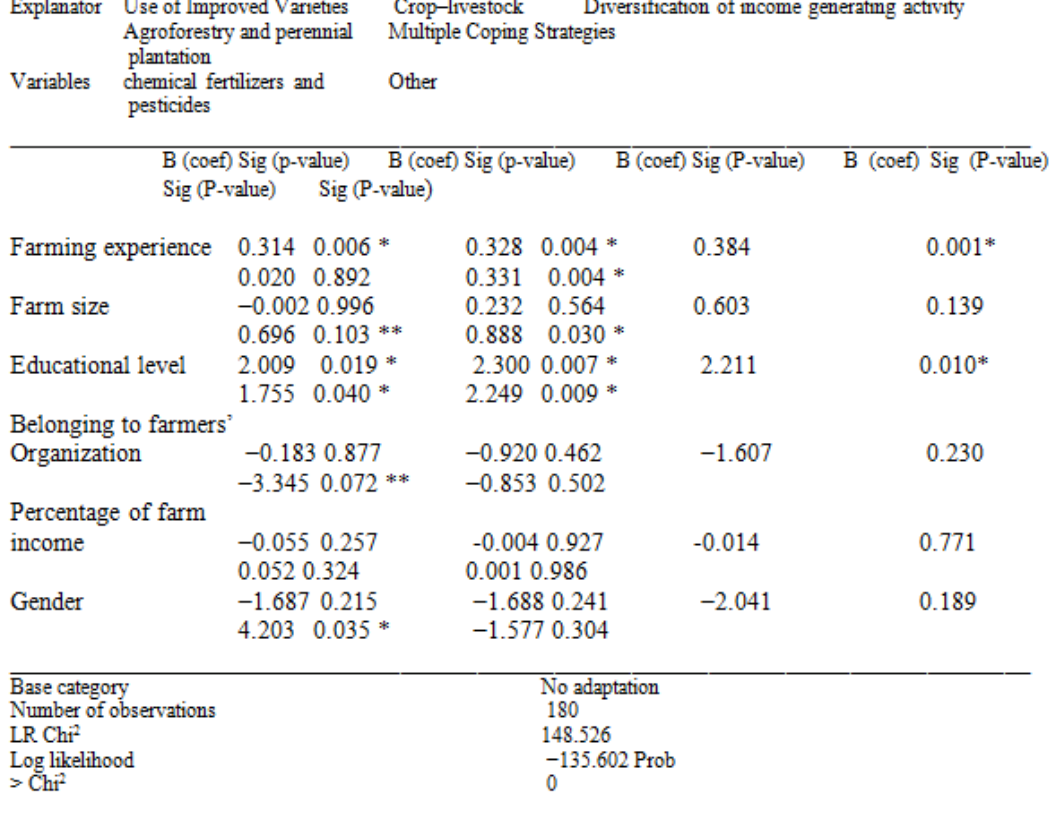

Table 5: Determinants of a Farmer's Choice to Use a Specific Climate Change Adaptation Strategy ${ }^{*}$ And ${ }^{* *}$ Significant at 5\% and 10\% Probability Level, Respectively

\section{Discussion}

\subsection{Farmers' Perceptions of an Adaptation Strategies to Climate Change}

Apart from 20\%, other farmers are perceived a change in the climate, which indicates that they are well aware. This is in-line with other studies (Fosu-Mensah 2010, Mustapha et al. 2012, Muzamhindo et al. 2015). Rainfall delays, before time termination, bad rainfall distribution are the most common changes. These findings are in line with many studies in Benin (Loko et al. 2012), Niger (Assoumana et al. 2016), Nigeria (Mustapha et al. 2012) and Kenya (Gebreeyesus, 2017). Similar type of study has been conducted in Tanzania and Senegal has been reported (Cochet et al. 2017). But this result is contradictory with the study done by Fosu-Mensah (2010) where only a few farmers have developed adaptation strategies. Adaption strategies include use of improve fertilizers, re-planning of agricultural calendar, checking and proper management of soil fertility (Maddison, 2007; Nhemachena and Hassan, 2007; Bryan et al., 2009; Fosu-Mensah (2010; Mustapha et al. 2012; Loko et al. 2013). Many other studies also talk about these types of adaption strategies (Tazeze et al. 2012, Loko et al. 2013, Sani and Chalchisa, 2016). This research also revealed that educational level significantly influenced all adaptation strategies, lust like it is maintained in some other studies (Tazeze,2012;Assoumana, 2016; Gbetibouo (2009; Gbetibouo, 2009). Farm size also has association with selecting strategies. This is in-line with Sani \&Chalchisa (2016).

\subsection{Implications of Farmers' Choices}

Farmers' choices on adoption of given adaptation strategies could have two purposes; either for expected profit or avoiding risk. All strategies developed by farmers to adapt to climate change fit into these two purposes.

Another major strategy is agroforestry and perennial plantation. Many studies have shown that agroforestry may offer many economic and environmental benefits (Zoysa and Inoue, 2014). According to Zoysa and Inoue (2014), agroforestry has an important role in climate change adaptation by enhancing resilience to climate impacts on farming systems. Torquebiau (2013) reported that agroforestry has a double potential to address climate change issues: greenhouse gas mitigation strategy through carbon sequestration and sustainable adjustment to changing conditions (because agroforestry systems can be called perennial farming systems). More than an adaptation strategy, agroforestry is a mitigation strategy. Agroforestry is a landscape-scale approach, thus favors synergy between adaptation and mitigation Torquebiau (2013). Apart from its socioeconomic benefits (Bugayong, 2003), agroforestry, through its effects on soil conservation, protection of biodiversity, carbon sequestration (Murthy et al. 2016) is the most sustainable strategy.

\subsection{Barriers to Effective Adaptation}

Several studies carried out in Africa pointed out many barriers, which challenged the ability of farmers to adapt to climate change. The main barriers identified are: institutional factors, access to credit, lack of information and irregularity of extension services (Juana et al. 2013, Assoumana et al. 2016) reported that the institutional factors that influence adoption of new technologies are access to information via extension services (climate information and production technologies) and access to credit. According to the same author, farmers who have significant extension contacts have better chances of being aware of changing climatic conditions as well as adaptation measures in response to the changes in these conditions. This is confirmed by the findings of Assoumana (2016). Sani \&Chalchisa (2016) further.

In South-Kivu province and particularly in KBNP surrounding areas, adjustment strategies are especially reactive and their adoption by agroeco systems exploiters is very slow and in the government programs, the adjustment of the 
sector of the feeding production to climate change is not yet among priorities (Byenda et al. 2019). The good news for DRC is that, the inherent resilience of the country ecosystems gives hope for sustainable development pathways into the future. Indeed, the government of the DRC has recently incorporated climate change in its development policy documents. Implementation of the United Nations Framework Convention on Climate Change, management and protection of forests and the environment to enhance their rights and improve their living conditions can be achieved.

\section{Conclusions and Policy Implications}

This study indicated that the farmers of the KBNP surrounding areas are well aware of the climate change perception and its impacts on the agricultural production. This study also highlighted that their family also has the perception regarding the climate change (Cochet et al. 2017). For implementation of proper policies, adequate knowledge and understanding of risks are very important (Juana et al. 2013).

A number of policy conclusions can be drawn from this study. First of all, it is important to analyze the impacts of climate change on agriculture and simultaneously understand the drivers behind farmers adaptation. Secondly, the current attention given to climate adaptation has the potential to go hand-in-hand with the long-term policy priority in increasing production and reducing vulnerability among poor farmers in developing countries. The great potential for effective policy intervention is particularly evident from the factors that affect climate change adaptation. Many of the significant factors can be addressed as part of rural development programs, such as literacy, formal extension, access to formal credit and provision of information about climate variables and adaptation options.

One particularly important issue of climatological is that the trend for declining rainfall in the rainy season. This generally happens in opposition with climate model projections that increases in rainfall (Funk et al. 2008). It might be influenced by Pacific Ocean sea surface temperature patterns (Lyon and DeWitt, 2012). The pattern of land use and the conversion of wild lands are most serious threats (Plumptre, 2012). For farmers it is a long-back continuous problem (Thornton et al. 2009). Building up resilience reduces vulnerability to a wide range of hazards and in this way helps farmers and communities prepare for the uncertainties ahead.

Among possible consequences from climate change impacts on food provision and agriculture derived from these findings and other climate-related factors are the following: (i) Agricultural yield, the model depicts substantial losses for maize and bean yields throughout the Albertine Rift; (ii) Wildlands conversion to farmland. The building stresses upon cultivation appear to be maximized at lower elevation, particularly in the densely populated areas proximal to the KBNP highland sector. At the same time, highland areas currently occupied by some of the region's remaining stands of montane forest are shown to offer increasing potential for cultivation (Belfiore, 2010; Plumptre, 2012).

However, in most PAs surroundings, two or more factors have already manifested urging immediate action, even before the comprehensive climate assessment of the territory is accomplished. Where this is the case, climate information can help appropriately substantiate investment demand and develop future scenarios. Statistically, an investment demand for climate change adaptation is 20-30 or more times lower, than climate change damage estimate where no adaptation measures are taken (Semenov et al. 2012).

Future research can be conducted on the topic of microeconomics of the adaptation process especially on practical adaptation options, not only for agriculture but also for non-agricultural livelihoods. On the climate change in rural areas, there is also a need to conduct research. More research is needed on vulnerability, to identify the most vulnerable areas, populations, and social categories.

The availability of micro panel data can provide more robust evidence on both the role of adaptation and its implications for productivity. Future research efforts should also be devoted to the distinction of the different adaptation strategies and the identification of the most successful ones for both the medium and longer term.

\section{References}

i. Adger, N. 2006. Vulnerability. Glob. Environ. Chang. 268-281.

ii. Adger WN, Huq S, Brown K, Conway D, Hulme M. 2003. Adaptation to climate change in the developing world. Prog Dev Stud 3(3):179-195.

iii. Ahmed, S.; Deffenbaugh, N.; Hertel, T.; Lobell, D.; Ramankutty, N.; Rios, A.; Rowhani, P. Climate volatility and poverty vulnerability in Tanzania. 2011. Glob. Environ. Chang. 21, 46-55.

iv. Assoumana, B.T. ; Ndiaye, M. ; Puje, G. ; Diourte, M. ; Graiser, T. 2016. Comparative Assessment of Local Farmers' Perceptions of Meteorological Events and Adaptations Strategies: Two Case Studies in Niger Republic. J. Sustain. Dev. 9, 118-135.

v. Bashir MK, Schilizzi S. 2013. Determinants of rural household food security: a comparative analysis of African and Asian studies. J Sci Food Agric 93(6):1251-1258.

vi. Beddington J, Asaduzzaman M, Clark M et al. 2012. Achieving food security in the face of climate change: Final report from the commission on sustainable agriculture and climate change. CGIAR Research Program on Climate Change, Agriculture and Food Security (CCAFS). Copenhagen, Denmark.

vii. Belfiore, N.M, (ed.). 2010. The Implications of Global Climate Change for Mountain Gorilla Conservation. African Wildlife Foundation, the International Gorilla Conservation Programme, and EcoAdapt.

viii. Below, T.; Schmid, J.; Sieber, S. 2015. Farmers' knowledge and perception of climatic risks and options for climate change adaptation: A case study from two Tanzanian villages. Reg. Environ. Chang. 15, 1169-1180.

ix. Brown ME, Hintermann B, Higgins N. 2009. Markets, climate change, and food security in West Africa. Environ Sci Technol 43(21):8016-8020. 
x. Bryan, E., T.T. Deressa, G.A. Gbetibouo, and C. Ringler. 2009. Adaptation to climate change in Ethiopia and South Africa: options and constraints. Environmental Science and Policy, 12, 413-426.

xi. Bugayong, L.A. 2003. Socioeconomic and Environmental Benefits of Agroforestry Practices in a Communitybased Forest Management Site in the Philippines. In Proceedings of the International Conference on Rural Livelihoods Forests and Biodiversity, Bonn, Germany, 19-23 May 2003.

xii. Byenda, MB., Kanyenga, LA., Baluku, BJP., Munyuli, MT and Baboy, LL. 2019. Adaptation endogène des agroécosystèmes et de la sécurité alimentaire aux perturbations et changement climatiques au Sud-Kivu (RD Congo). International Journal of Innovation and Applied Studies ISSN 2028-9324 Vol. 25 No. 2 pp. $605-622$

xiii. Challinor A, Wheeler T, Garforth C, Craufurd P, Kassam A. 2007. Assessing the vulnerability of food crop systems in Africa to climate change. Clim Chang 83(3):381-399.

xiv. Christy, J.R., Norris, W.B. and McNider, R. T. 2009. Surface temperature variations in east Africa and possible causes. Journal of Climate 22, 3342-3356.

xv. Cirimwami, KJP., Ramananarivo, SB., Mutabazi NA., Muhigwa, BJB., Ramananarivo, R. et Bisimwa, BE. 2020. Crise agricole au Sud-Kivu montagneux en RD Congo : Chute continue, stagnation ou évolution en dents de scie de la production des chefferies. IOSR Journal of Environmental Science, Toxicology and Food Technology (IOSR-JESTFT), ISSN: 2319-2399.Volume 14, Issue 4, PP 26-48.

xvi. Cirimwami, KJP., Ramananarivo, SB., Mutabazi NA., Muhigwa, B., Bisimwa, EB., Romaine Ramananarivo, R et Jules Razafiarijaona, J. 2019. Changementclimatique et production agricole dans la région du Sud-Kivu montagneux à l'Est de la RD Congo [ Climate change and agricultural production in the mountainous South Kivu region of Eastern DR Congo] International Journal of Innovation and Applied Studies ISSN 2028-9324 Vol. 26 (2), 526-544.

xvii. Cochet, H., Ducourtieux, O., Garambois, N. 2017. Systèmes agraires et Changement climatique : Les chemins de l'adaptation; Working Paper ; AgroParisTech : Paris, France.

xviii. Cunguara, B. and I. Darnhofer, 2011: Assessing the impact of improved agricultural technologies on household income in rural Mozambique. Food Policy, 36(3), 378-390.

xix. Deressa, T. T., Hassan, R. M., Ringler, C., Alemu, T. \&Yesuf, M. 2009. Determinants of farmers' choice of adaptation methods to climate change in the Nile Basin of Ethiopia. Global Environmental Change 19, $248-255$.

xx. Diamond, J. 1997. Gun, Germs and Steel: The Fates of Human Societies, Norton Publishers, New York.

xxi. Fedoun F, Sonwa D, Kemeuze V, Mengelt C. 2017. Urban climate assessing climate change vulnerability and local adaptation strategies in adjacent communities of the Kribi-Campo Coastal. Urban Climate 10: 1.

xxii. Fischer, E., 1996. Die Vegetation des Parcs National de Kahuzi-Biéga, Sud-Kivu, Zaïre [The vegetation of KahuziBiega national park, South-Kivu, Zaire] (Stuttgart: Franz Steiner Verlag), p. 238.

xxiii. Food and Agriculture Organization of the United Nations (FAO). 2005. Irrigation in Africa in figures AQUASTAT Survey - 2005. FAO Water Reports No

xxiv. Fosu-Mensah, B.Y.; Vlek, P.L.G.; Manschadi, A.M. Farmers' Perception and Adaptation to Climate Change; A Case Study of Sekyedumase District in Ghana. In Proceedings of the World Food System-A Contribution from Europe Farmers', Tropentag, Zurich, Switzerland, 14-16 September 2010.

xxv. Funk, C, Dettinger, M.D, Michaelsen, J.C, Verdin, J. P, Brown, M.E, Barlow, M. and Hoell. A. 2008. Warming of the Indian Ocean threatens eastern and southern African food security but could be mitigated by agricultural development. Proceedings of the National Academy of Science USA, 105: 11081-6.

xxvi. Gbetibouo, G. A. 2009. Understanding Farmers' Perceptions and Adaptations to Climate Change and Variability: The Case of the Limpopo Basin, South Africa. IFPRI Discussion Paper No. 00849. Washington, DC: IFPRI. Available online at: http://www.ifpri.org/publication/ understanding-farmers-perceptions-andadaptationsclimate-change-and-variability (verified 14 June 2010).

xxvii. Gebreeyesus, K.A. 2017. Impact of Climate Change on the Agro-ecological Innovation of Coffee Agroforestry Systems in Central Kenya. Ph.D. Thesis, SupAgro, Montpellier, France.

xxviii. Gleick, P. 2012. Climate change, disbelief, and the collision between human and geologic time. Forbes. Retrieved from http://www.forbes.com/sites/petergleick/16 June 2020/climate-change-disbelief-and-the-collisionbetween-humanand-geologic-time/.

xxix. Hannah, L. 2008. Protected Areas and Climate Change. Ann. N.Y. Acad. Sci. 1134: 201-212.

xxx. Hassan, R., 2010: The double challenge of adapting to climate change while accelerating development in subSaharanAfrica. Environment and Development Economics, 15, 661-685

xxxi. Hassan, R. and C. Nhemachena. 2008. Determinants of African farmers' strategies for adapting to climate change: multinomial choice analysis. African Journal of Agriculture and Resource Economics, 2(1), 83-104.

xxxii. Herrmann, S. M. and K.I. Mohr, 2011: A Continental Scale Classification of Rainfall Seasonality Regimes in Africa Based on Gridded Precipitation and Land Surface Temperature Products. Journal of Applied Meteorology and Climatology, 50: 2504-2513.

xxxiii. Intergovernmental Panel on Climate Change (IPCC). 2014. Climate Change Impacts. Adaptation, and Vulnerability. Part A: Global and Sectoral Aspects. Contribution of Working Group II to the Fifth Assessment Report of the Intergovernmental Panel on Climate Change; Field, C.B., Barros, V.R., Estrada, R.C., Genova, B., Girma, E.S., Kissel, A.N., Levy, S., MacCracken, P.R., Mastrandrea, L.L., Eds.; Cambridge University Press: Cambridge, UK; New York, NY, USA.

xxxiv. IPCC. 2012. Managing the risks of extreme events and disasters to advance climate change adaptation. In A Special Report of Working Groups I and II of the Intergovernmental Panel on Climate Change; Field, C.B., 
Barros, V., Stocker, T.F., Qin, D., Dokken, D.J., Ebi, K.L., Mastrandrea, M.D., Mach, K.J., Plattner, G.-K., Allen, S.K., et al., Eds.; Cambridge University Press: Cambridge, UK.

xxxv. IPCC. 2007. Summary for Policymakers. In: Climate Change. 2007. The Physical Science Basis. Contribution of Working GroupI to the Fourth Assessment Report of the Intergovernmental Panel on Climate Change [Solomon, S., D. Qin, M. Manning, Z. Chen, M. Marquis, K.B. Averyt, M. Tignor and H.L. Miller (eds.)]. Cambridge University! Press, Cambridge, United Kingdom and New York, NY, USA.

xxxvi. Juana, J.S.; Kahaka, Z.; Okurut, F.N. 2013. Farmers' Perceptions and Adaptations to Climate Change in SubSahara Africa: A Synthesis of Empirical Studies and Implications for Public Policy in African Agriculture. J. Agric Sci. 5, 121-135.

xxxvii. Kebede A, Hasen A, Negatu W. 2011. A comparative analysis of vulnerability of pastoralists and agropastoralists to climate change: a case study in Yabello Woreda of Oromia Region, Ethiopia. Ethiop J Dev Res 33(1):61-95.

xxxviii. Kilembe, C.; Thomas, T.S.; Waithaka, M.; Kyotalimye, M.; Tumbo, S. 2012. East African Agriculture and Climate Change: A Comprehensive Analysis-Tanzania; IFPRI: Washington, DC, USA.

xxxix. Langyintuo, A.S. and C. Mungoma, 2008: The effect of household wealth on the adoption of improved maize varieties in Zambia. Food Policy, 33(6), 550-559.

xl. Latif, M., Dommenget, D., Dima, M. and A. Grotzner.1999. The role of Indian Ocean sea surface temperature in forcing East African rainfall anomalies during December- January 1997/98, Journal of Climate, 12 : 3497 3504.

xli. Locatelli B, Markku K, Brockhaus M, Colfer CJP, Murdiyarso D, Santoso H (2008) Facing an uncertain future. How forests and people can adapt to climate change. $100 \mathrm{p}$.

xlii. Loko, Y.L.;Dansi, A.; Agre, A.P.; Akpa, N.; Dossou-Aminon, I.; Assogba, P.; Dansi, M.; Sanni, A.; Akpagana, K. 2013. Perceptions paysannes et impacts des changements climatiques sur la production et la diversité variétale de l'igname dans la zone aride du nord-ouest du Bénin. International. J. Biol. Chem. Sci. 7, 672-695.

xliii. Lyon, B. and D. G. DeWitt. 2012. A recent and abrupt decline in the East African long rains, Geophysial Research Letters, 39: L02702.

xliv. Maddison D. 2007. The perception of and adaptation to climate change in Africa. World Bank Policy Research Working Paper 4308.

xlv. McCarl BA. 2010. Analysis of climate change implications for agriculture and forestry: an interdisciplinary effort. Clim Chang 100:119-124. doi:10.1007/s10584-010-9833-6.

xlvi. Mendelsohn, R., Dinar, A., \& Williams, L. 2006. The distributional impact of climate change on rich and poor countries. Environment and Development Economics, 11, 1-20.

xlvii. Mendelsohn, R., Dinar, Y. and Dalfelt, A. 2000. Climate Change Impacts on African Agriculture. Yale University andMission Statement. FDRE, Addis Ababa

xlviii. Misselhorn, A. 2005. What drives food insecurity in southern Africa? A meta-analysis of household economy studies. Glob Environ Chang 15:33-43.

xlix. Moumouni, I. and L. Idrissou. 2013. Innovation Systems for Agriculture and Climate in Benin: Analysis of Three Case-Studies from Benin. Climate Learning for African Agriculture Working Paper No.5 [Morton, J. and P. Govinden (trans.)]. African Forum forAgricultural Advisory Services (AFAAS), Forum for Agricultural Research in Africa (FARA), and Natural Resources Institute (NRI), University of Greenwich, NRI, Kent, UK, 23 pp.

l. Murthy, I.K.; Dutta, S.; Varghese, V.; Kumar, P. 2016. Impact of Agroforestry Systems on Ecological. Glob. J. Sci. Front. Res. 16, 15-28

li. Mustapha, S.B.; Sanda, A.H.; Shehu, H. 2012. Farmers' Perception of Climate Change in Central Agricultural Zone of Borno State, Nigeria. J. Environ. Earth Sci. 2, 21-28.

lii. Muzamhindo, N.; Mtabheni, S.; Jiri, O.; Hanyani-Mlambo, B. 2015. Factors Influencing Smallholder Farmers' Adaptation to Climate Change and Variability in Chiredzi District of Zimbabwe. J. Econ. Sustain. Dev. 6, 1-9.

liii. Ngaira, JKW and Morgan Musiambo, M. 2012. 'Climate Change and Agricultural Development in Africa: Solutions and Challenges to Persistent Famine' International Journal of Asian Social Science, Vol.2, No.2. pp.153-168.

liv. Nhemachena, C. \& Hassan, R. 2007. Micro-level analysis of farmers' adaptation to climate change in Southern Africa. IFPRI Discussion Paper No. 00714. International Food Policy Research Institute, Washington, D.C.

lv. Niang, I., Ruppel, O.C., Abdrabo, M.A., Essel, A., Lennard, C., Padgham, J., Urquhart, P., 2014. Africa. In : Barros, V.R., Field, C.B., Dokken, D.J., Mastrandrea, M.D., Mach, K.J., Bilir, T.E., Chatterjee, M., Ebi, K.L., Estrada, Y.O., Genova, R.C., Girma, B., Kissel, E.S., Levy, A.N., MacCracken, S., Mastrandrea, P.R., White, L.L. (Eds.), Climate Change 2014 : Impacts, Adaptation, and Vulnerability. Part B: Regional Aspects. Contribution of Working Group II to the Fifth Assessment Report of the Intergovernmental Panel on Climate Change. Cambridge University Press, Cambridge, United Kingdom and New York, NY, USA, pp. 1199-1265.

lvi. Ntahombagana, MC. 2019. Approvisionnement de la ville de Bukavu en bois d'œuvres et bois énergie en provenance Kalonge et Bunyakiri en territoire de Kalehe dans le Sud-Kivu : menaceset opportunités. Mémoire de licence, ISDR/Bukavu. 86 p.

lvii. Nyamunyere, MI. 2019. Perception de la population sur les changements climatiques et ses impacts sur la production agricole dans le territoire de Kabare : cas du manioc et bananes. Mémoire de licence, ISDR/Bukavu. $63 \mathrm{p}$. 
lviii. Paavola, J. 2008. Livelihoods, vulnerability and adaptation to climate change in Morogoro, Tanzania. Environmental Science \& Policy 11, pp. 642-654.

lix. Plattner, G.-K., Allen, S.K., et al., Eds.; Cambridge University Press: Cambridge, UK, 2012.Intergovernmental Panel for Climate Change (IPCC) (2007) In: Parry ML, Canziani OF, Palutikof JP, van der Linden PJ, Hanson CE (eds) Climate change 2007: Impacts, adaptations and vulnerability. Contribution of Working Group II to the Third Assessment Report of the Intergovernmental Panel on Climate Change. Cambridge University Press, Cambridge, $1000 \mathrm{p}$.

lx. Plumptre, A. J. (ed.). 2012. The Ecological Impact of!Long-term Changes in Africa’s Rift Valley. New!York: Nova Science Publishers.

lxi. Plumptre, A.J., Kujirakwinja, D., Matanguru, J., Kahundo, C., Kaleme, P., Marks, B. et Huhndorf, M. 2008. Inventairesbiologiques des régions de Misotshi-Kabogo (Mont et Marungu à l'est de la RDC) [Biologic inventories of the regions of Misotshi-Kabogo (Marungu Mountain from the East of DRC)]. Albertine Rift Technical Report 8 (Wildlife Conservation Society).

lxii. Porter JR, Xie L, Challinor AJ, Cochrane K, Howden SM, Iqbal MM, Lobell DB, Travasso MI. 2014. Food security and food production systems. In: Field CB, Barros VR, Dokken DJ, Mach KJ, Mastrandrea MD, Bilir TE, Chatterjee M, Ebi KL, Estrada YO, Genova RC, Girma B, Kissel ES, Levy AN, MacCracken S, Mastrandrea PR, White LL (eds) Climate change 2014: impacts, adaptation, and vulnerability. Part A: global and sectoral aspects. Contribution of working group II to the fifth assessment report of the intergovernmental panel on climate change. Cambridge University Press, Cambridge, pp 485-533.

lxiii. Ringler, C. 2010. Climate change and hunger: Africa's smallholder farmers struggle to adapt. Euro Choices, 9(3), 16-21.

lxiv. Rowhani, P.; Lobell, D.B.; Linderman, M.; Ramankutty, N. 2011. Climate variability and crop production in Tanzania. Agric. For. Meteorol. 15, 449-460

lxv. Sani, S. andChalchisa, T. 2016. Farmers' Perception, Impact and Adaptation Strategies to Climate Change among Smallholder Farmers in Sub-Saharan Africa: A Systematic Review. J. Ressour. Dev. Manag. 26, 1-8.

lxvi. Sani, S. 2014. Climate Change Adaptation Strategies of Smallholder Farmers: The Case of Assosa District of Benishangul Gumuz Regional State, Western Ethiopia; Haramaya University: Haramaya, Ethiopia.

lxvii. Semenov S.M. (Ed.). 2012. Methods to evaluate implications of climate change for physical and biological systems / S.M. Semenov (Ed.). Moscow:Roshydromet. 511 p.

lxviii. Shongwe, Mxolisi, E., Geert Jan van Oldenborgh, Bart van den Hurk, Maarten van Aalst. 2011. Projected Changes in Mean and Extreme Precipitation in Africa under Global Warming. Part II: East Africa. Journal of Climate, 24: 3718-3733.

lxix. Sieber, S.; Tscherning, K.; Graef, F.; Sergio, U.; Paloma, G. 2015. Food security in the context of climate change and bioenergy production in Tanzania: Methods, tools and applications. Reg. Environ. Chang. 15, 1163-116.

lxx. Simelton, E.; Quinn, C.H.; Batisani, N.; Dougill, A.J.; Dyer, J.C.; Fraser, E.D.G.; Mkwambisi, D.; Sallu, S.; Stringer, L.C. Is rainfall really changing? 2013. Farmers' perceptions, meteorological data, and policy implications. Clim. Dev. 5, 123-138.

lxxi. Songok CK, Kipkorir EC, Mugalavai EM. 2011. Integration of indigenous knowledge systems into climate change adaptation and enhancing food security in Nandi and Keiyo districts, Kenya. In: Filho WL (ed) Experiences of climate change adaptation in Africa. Springer, Hamburg, pp 69-95.

lxxii. Sonwa DJ, Somorin OA, Jum C, Bele MY, Nkem JN (2012) Vulnerability, forest-related sectors and climate change adaptation: The case of Cameroon. For Policy Econ

lxxiii. Sovacool, B.; Linnér, B.; Klein, R. 2017. Climate change adaptation and the Least Developed Countries Fund (LDCF): Qualitative insights from policy implementation in the Asia-Pacific. Clim. Chang. 140, 209-226.

lxxiv. SPSS. 2017. Statistical Package for Social Sciences (SPSS): Advanced Statistics Version 25. IBM Corp. Released 2017. IBM SPSS Statistics for Windows, Version 25.0. Armonk, NY: IBM Corp.

lxxv. Stampone, M.D., J. Hartter, C.A. Chapman and S.J. Ryan. 2011. Trends and Variability in Localized Precipitation Around Kibale National Park, Uganda, Africa. Research Journal of Environmental and Earth Sciences 3:14-23.

lxxvi. Stem, N. 2007. Stern Review on the Economics of Climate Change. Cambridge, UK: Cambridge University Press.

lxxvii. Tazeze, A.; Haji, J.; Ketema, M. 2012. Climate Change Adaptation Strategies of Smallholder Farmers: The Case of Babilie District, East Harerghe Zone of Oromia Regional State of Ethiopia. J. Econ. Sustain. Dev. 3, 1-13. 23.

lxxviii. Tesfahunegn F, Gebreyesus B, Kirubel M, Abadi T.2016. Farmer's perception on causes, indicators and determinants of climate change in Northern Ethiopia: Implication for developing adaptation strategies. Applied Geography 73: 1-12.

Ixxix. Thomas DSG, Twyman Ch, Osbahr H, Hewitson B. 2007. Adaptation to climatic change and variability: farmer responses to intra-seasonal precipitation trends in South Africa. Clim Change 83:301-322.

lxxx. Thompson J, Scoones I. 2009. Addressing the dynamics of agri-food systems: an emerging agenda for social science research. Environ Sci Policy 12(4):386-397

lxxxi. Thornton, P.K., P.G. Jones, G. Alagarswamy and J. Anresen. 2009. Spatial variation of crop yield response to climate change in East Africa. Global Environmental Change, 19: 54-65.

lxxxii. Tierney, J.E., Russell, J.M., SinningheDamsté, J.S., Huang, Y., Verschuren, D. 2011. Late Quaternary behavior of the East African monsoon and the importance of the Congo Air Boundary. Quaternary Science Reviews, 30: 798-807.

lxxxiii. Torquebiau, E. 2013. Agroforestry and Climate Change; Working Paper; CIRAD: Montpellier, France. 
lxxxiv. Weber, E. U. 2010. What shapes perceptions of climate change? Wiley Interdisciplinary Reviews: Climate Change, $1,332-342$.

lxxxv. White, F. 1986. La végétation de l'Afrique. Mémoire accompagnant la carte de végétation de l'Afrique UNESCO/AETFAT/UNSO. Recherches sur les Ressources Naturelles, $\mathrm{n}^{\circ}$ 20. The vegetation of Africa. Camp accompanied by map of Africa vegetation.

lxxxvi. UNDP.2006. Human Development Report 2006. Beyond Scarcity: Power, Poverty and the global water crisis, UNDP.

lxxxvii. Zoysa, M.D.; Inoue, 2014. M. Climate Change Impacts, Agroforestry Adaptation and Policy Environment in Sri Lanka. J. For. 4, 439-456. 